\title{
The sensory acceptance of fibre-enriched cereal foods: a meta-analysis
}

Grigor, John M., Brennan, Charles S., Hutchings, Scott C., and Rowlands, David S.

This is the peer reviewed version of the following article:

Grigor, J.M., et al. 2016. The sensory acceptance of fibre-enriched cereal foods: a meta-analysis. International Journal of Food Science \& Technology

which has been published in final form at doi:

http://dx.doi.org/10.1111/ijfs.13005

This article may be used for non-commercial purposes in accordance with the Wiley Terms and Conditions for Self-Archiving 
The sensory acceptance of fibre enriched cereal foods: A meta-analysis

J.M. Grigor ${ }^{1}$, C.S. Brennan ${ }^{2}$, S.C. Hutchings ${ }^{3}$ and D.S. Rowlands ${ }^{4}$

${ }^{1}$ School of Science, Engineering and Technology, Abertay University, Dundee, Scotland

${ }^{2}$ Centre of Food research and Innovation, Lincoln University, Christchurch, New Zealand

${ }^{3}$ UCD Institute of Food and Health, University College Dublin, Belfield, Dublin, Ireland

${ }^{4}$ School of Sport and Exercise, Massey University, Wellington, New Zealand

Address for reprint requests and other correspondence: D. S. Rowlands, School of Sport and Exercise, Massey Univ., 63 Wallace St., Mt. Cook, Wellington 6011, New Zealand (e-mail: D.S.Rowlands@massey.ac.nz). 


\section{ABSTRACT}

2 Improved understanding of the sensory responses to fibre fortification may assist manufacturers and

3 health promotion efforts. The effects of fibre fortification (or modified ingredients) on sensory

4 acceptability of baked cereal foods (bread, cookies, muffins) were estimated by linear random

5 effects meta-analysis of 20 eligible studies (869 panelists, $34 \%$ male). As little as $2 \mathrm{~g} / 100 \mathrm{~g}$

6 fortification caused moderate-large reductions in overall acceptability, flavour acceptability, and

7 appearance acceptability in most items, with cookies most negatively affected. Fortification of base

8 non-fortified foods with low initial acceptability improved acceptability; however, at higher basic

9 levels, fortification lowered acceptability. Fortification improved texture acceptability of muffins and

10 bread with low base acceptability, but lowered texture acceptability when base acceptability was

11 high. Flavour improvement of muffins with fortification decreased with increasing base food

12 acceptability. Fiber fortification of baked cereal foods lowers acceptability, but food format and base-

13 food acceptability affects the magnitude and direction of responses. Refining fiber-fortification

14 approaches could improve consumer uptake.

16 Running Head: Fiber fortification: meta-analysis

17 Key Words: Dietary Fibre, Additives, Baking, Food/Feed Fortification 
Increased dietary fibre consumption is associated with a lower risk of both cardiovascular disease and coronary heart disease (Threapleton, et al., 2013), colorectal cancers (Murphy, et al., 2012) obesity and maturity onset diabetes (Papathanasopoulos, and Camilleri, 2010). An increasing number of foods have been developed to specifically deliver fibre enrichment through everyday products, such as, bread, fruit drinks, pasta, muffins, cookies and breakfast cereals. However, these new products and communication campaigns encouraging increasing dietary fibre consumption (Snyder, 2008, Slavin, 2008), from a population average has not yet reached target dietary reference values in some countries. For example, in the United Kingdom a survey spanning 2007/2008 and 2011/2012 (a four year program) has population consumption of non -starch polysaccharides at 13.7-13.9 g per day for an adult which falls noticeably short of the Dietary Reference Value (DRV) of consumption currently at $18 \mathrm{~g}$ per person per day (Food Standards Agency, 2014). In the USA dietary fibre has been reported as being under consumed with an average population consumption of 15 g/day (U.S. Department of Agriculture and U.S. Department of Health and Human Services, 2010).

Purchase, and more so repeat purchase, of food products by consumers are based on a number of psychological and physiological factors (Bruns $\varnothing$, Fjord, \& Grunert, 2002). However, most consumer research investigates specific quality (in particular the flavour and texture of the foods) as being the most important factor in selection rather than consumer repurchasing patterns. Outcomes from consumer based surveys indicate that healthy foods are perceived to be less tasty by consumers (Kearney \& McElhone, 1998). Furthermore, consumers are reluctant to compromise on taste quality for health benefits offered by fiber-fortified foods (Datamonitor, 2009). A consumer belief system may be emerging that there is no need for a trade-off in regards to healthy and good eating (Verbeke,2006). There is also evidence that the food market is distinctly segmented with 
regards to attitudes towards functional foods (Barker, 1995; Frewer et al. 2003) with a large segment, related to lower socio-economic status, unmotivated in making choices towards high fibre food options to promote healthy eating. Therefore, designing high fibre foods with broader appeal and driving these products from a niche market to a larger market is a priority (Datamonitor, 2009). New sources of dietary fibre may confer significant health benefits (Rodríguez et al., 2006). In particular, fibre extracts from fruits (e.g. citrus, apples, mangoes, kiwi fruits) or vegetables (asparagus, pumpkins and mushrooms to mention a few) may also cause beneficial co-extraction of bioactive compounds, such as, flavanoids and carotenoids (Bangoura et al., 2013; Gelinas, 2013). Therefore, how novel and traditional fibre enriched products perform on an acceptability level when fortifying staple foods, such as bread is of great importance for the overall performance of such products in the market place and requires more attention. Consumer research requires large numbers of respondents to generate a reliable forecast of market acceptability - for which one study is unlikely to achieve. In addition, to understand population consumption patterns of dietary fibre requires population based information on product type and its effect on acceptability.

61

While meta-analyses are widespread and often at the top of the pyramid in translational research, to the authors knowledge this technique has not been applied to food consumer acceptability data. Therefore this study aims to: a) determine the effect of increased supplemental fibre dose on the sensory appeal of common fiber-fortified baked products by meta-analysis; b) review the effectiveness of this approach in understanding the fibre-mediated changes on sensory appeal, and c) undertake a brief critical evaluation of research quality in food-fibre research. 


\section{Article classification}

The data for this analysis was collected from original studies using the Web of Science database comprising the years 1998 to December 2013. The search strategy used the key terms dietary fibre, taste, fortification, flavour, texture, acceptability. Abstracts and title were then screened for relevance to the topic and full text articles were obtained where relevance was established. Further papers were investigated via any appropriate citations from the full text versions. Authors were contacted to request missing data that was needed to perform a meta-analysis, or for clarification. Inclusion criteria were: full papers published in peer reviewed journals in English, where the main purpose was to fortify a wheat based baked food product with a dietary fibre to enhance the healthiness of the product, and including perceptual ratings of the overall sensory acceptability of the fibre fortified food product as compared to a control (unfortified) food product. Twenty studies met the inclusion criteria (Table 1), with sixteen studies being excluded due to not enough data being generated to calculate dietary fibre content of the final product (Dhingra, \& Jood, 2001; Sangnark, \& Noomhorm, 2004a,b; Lieu et al., 2007, Torres et al., 2007, Haque, Shams-Ud-Din \& Haque, 2002, Girma et al., 2013; Gupta et al., 2011; Maziarz et al., 2013; Acosta et al., 2011; Yadav et al., 2012; Seremesic et al., 2013; Bagheri \& Seyedin, 2011; Lebesi \& Tzia; 2011; Waters et al., 2012). One study was eliminated (Hall et al., 2010) as the acceptability data was generated via a home use test with data being recorded four days and eighteen days with repeated consumption rather than via laboratory or central location testing. All studies selected were randomised cross-over designs. All studies provided multiple added-fibre dose contrasts, with comparisons categorised by food type: bread, muffins, and cookies (supplementary information). The number of contrasts depending on sensory outcome ranged from 6 to 46 . A total of 35 different intervention fibre form categories were experienced within the meta-analysis (fiber sources included: barley, apple, rice, lupin kernal, wheat, carob, pea, rice straw, sugar cane, 
lemon, sweet potato leaves, sweet potato stems, resistant starch, king palm residue, maize, oat, carboxymethyl cellulose/oligosaccharides mixes), with only one within-study fibre type contrast (Mialon et al., 2002); consequently, the impact of fibre form on outcomes was unable to be differentiated in this analysis. Additionally, cohort age and gender were reported, but there was insufficient reporting of information across studies to warrant inclusion of these two as covariates or predictors.

\section{Treatment of data for meta-analysis}

The amount of fibre fortification of the food product above the control value was normalised to $g$ fibre per $100 \mathrm{~g}$ of product. The effect of fibre fortification on all sensory acceptability scores (overall acceptability, texture acceptability, flavour acceptability, appearance acceptability) was linear regressed within the meta-analytical model against the within-contrast within-study treatment minus control fibre dose difference. The highest number of comparisons was for overall acceptability (supplementary material). Most authors utilised raw hedonic scales to assess sensory acceptability, with one utilising a 100 point acceptability scale (Masoodi, 1998). More detail of the acceptability scales used by authors is found in the supplementary information. Scales were all standardised to 0-100 point prior to analysis by dividing the sensory perception outcome by the scale maxima and multiplying by 100 . The meta SD used for final meta-analysed effect size calculation was generated from the square root of the unweighted mean of variances of the control food, for overall (all foods), and for the by food type, by sensory response analyses, respectively.

\section{Meta-Analysis Procedure}

The main outcome from this meta-analysis is the weighted mean of value of the outcome statistic from the various study comparisons, where the weighting factor is the comparison total sample size divided by the average sample size for all comparisons within a particular food and sensory 
category. Use of the inverse sampling standard error of the statistic derived from either the confidence interval or $P$ value of the outcome statistic or from SDs of change scores as the weighting factor as in standard random effects meta-analysis was not possible because too many studies presented a $P$ value inequality $(P>0.05$ or $P<0.05)$ or insufficient inferential information to permit a comparison analysis. To exclude all these studies from the meta-analyses would have resulted in unacceptable bias, akin to the publication bias that arises from failure of authors to submit studies or outcomes with non-significant outcomes or failure of journal editors to accept them. The meta-analytic outcomes from the current sample-size weighting method, nevertheless, is equivalent to that produced from the standard error method if it is assumed that the outcome has the same error of measurement in all studies (personal communication, W. G. Hopkins, 2007). The meta-analysis was performed with a program for the mixed modelling procedure (PROC MIXED) in the SAS (version 9.1; SAS Institute, Cary, NC). There were two terms with in the model statement: food was interacted with the fibre dose difference, and again with the fibre dose difference and the covariate. The key covariate was the value for the acceptability score for the baseline control food. Consequent to the model, the primary meta-analysed outcome was the change in the acceptability score, when the covariate and the fibre dose difference were the respective meta-analysed mean value. The effect of gender (expressed as the maleness fraction of the within-study cohort) and was added as a covariate, but resulted in no clear appreciable effect on outcomes so was excluded from the model. Outcomes were also analyzed by panel training status, where status was trained or untrained as defined by the authors of each article (Table 1).

Additionally, we re-ran the analysis with change in fibre dose scenarios of 2,5 , and $10 \mathrm{~g} / 100 \mathrm{~g}$, where the covariate was clamped at the meta-analysed mean. Furthermore, another analysis using standardised values for the covariate (acceptability score) of 40, 50, 60, 70, 80 standardised scale units was conducted to estimate the effect of the fibre content in the basic control food on the impact of subsequent fibre fortification on the texture acceptability, flavour acceptability, 
appearance acceptability and overall acceptability . After inclusion of the covariate, the remaining unexplained true variation within and between studies was estimated as a random effect. The meta-analyzed change in sensory perception was also expressed as standardized (Cohen) effects size (Cohen, 1988) by dividing by the meta SD. Magnitudes of the standardized effects were interpreted using thresholds of $0.2,0.6,1.2,2$, and 4 for small, moderate, large, very large, and extremely large effects, respectively, a modification of Cohen's thresholds of $0.2,0.5$, and 0.8 (Cohen, 1988); the modifications are based primarily on congruence with Cohen's thresholds for correlation coefficients (Hopkins, 2002). As a result, outcomes were qualified based on the effect size and the estimate uncertainty was presented as the $95 \%$ confidence limit.

\section{RESULTS}

\section{Descriptive Statistics}

The meta-analysis comprising 20 studies generated acceptability data for 869 reported panelists. Table 1 describes the information on the type of panelists that were used for each study. The major panelist type were employees or students of Universities in India, Europe, Turkey, Taiwan, Thailand, Australia, and Malaysia. The age range was 18 to 69 years. Study sample size varied between 7 to 103 . The fraction of male panelists was median 0.34 , with range 0 to 0.71 . One study cohort contained people with diabetes (Urooj et al., 1998).

\section{Average meta-analytical outcomes}

All studies reported outcomes for control (fibre unfortified) food items (Table 2). The sensory responses for control food on the normalized sensory acceptability scale (0-100) ranged from $66.8 \%$ for overall acceptability of Muffins through to $84.2 \%$ for overall acceptability of cookies, associated with food-fibre content of $4.5 \mathrm{~g} / 100 \mathrm{~g}$ and $3.3 \mathrm{~g} / 100 \mathrm{~g}$, respectively. The average quantity of fibre added to the basic food item represents the general quantity used or putatively 
utilized within a commercial fortified product. Subsequently, fibre fortification ranged from 3.1 $\mathrm{g} / 100 \mathrm{~g}$ for of bread through to $6.2 \mathrm{~g} / 100 \mathrm{~g}$ for cookies (Table 2). These fibre additions led to mean reductions in acceptability scores for all foods, with the only exception being a mean improvement in the acceptability of texture with muffins (Table 2).

177

Figure 1 presents the standardized effects of fibre fortification on food acceptability. Metaanalytical mean fibre fortification had a mostly large to very large reducing effect on all a c c e ptability sensory responses when all foods were grouped together. Cookies were most negatively affected by fortification (enormously detrimental). Mean fibre fortification of bread did not clearly affect overall acceptability, texture acceptability, and flavour acceptability relative to muffins, but the acceptability of appearance of bread was on average improved by fortification relative to muffins (Figure 1). Relative to muffins and cookies, the addition of fiber to cookies had a very large negatively impact on overall acceptability, texture, flavour and appearance acceptability.

The effect of panel training status on outcomes was largely consistent unclear, with any differences in the mean response lying well within the $95 \%$ uncertainty range for the individual by-panel response. The exceptions were moderate $-0.9(95 \% \mathrm{Cl},-1.9$ to $0.2 \%)$ and $-1.2(-2.6$ to 0.3$)$, and an enormous $6.9(-10.9$ to -2.9$)$ standardized change in the overall acceptability score in the trained cohort vs. untrained cohorts in response to the meta-mean fiber fortification dose for all foods, bread, and cookies. Also of note was a large standardised increase in flavor acceptability in trained vs. untrained panelists $(1.9,95 \% \mathrm{Cl}-0.1$ to 4.0$)$ with the addition of the meta-mean fibre dose. All other differences between panel training status (not shown for brevity) were considered inconclusive or negligible ( $p$ value $>0.15$; more data required).

\section{Effect of increasing fibre supplementation}

Figure 2 presents the standardized effects of increasing fibre fortification on food acceptability. 
The model response is for decreased acceptability scores when fortification is increased from the meta-analytical non-fortified basic control food. As little as $2 \mathrm{~g} / 100 \mathrm{~g}$ unit increase in fibre resulted in large reductions in overall acceptability for all foods, cookies and bread, and a moderate reduction for muffins. Acceptability of texture and flavour at a $2 \mathrm{~g} / 100 \mathrm{~g}$ unit increase in fibre fortification showed a moderate reduction in all foods, a small and moderate reduction respectively for muffins, a large and moderate reduction respectively for bread and large reductions for cookies (though the uncertainty allowed for trivial to very large effects ). A $2 \mathrm{~g} / 100 \mathrm{~g}$ increase in fibre fortification generated greater negative acceptability responses to appearance with very large reductions observed for all foods, muffins and cookies and large reduction observed for bread. A $5 \mathrm{~g} / 100 \mathrm{~g}$ and $10 \mathrm{~g} / 100 \mathrm{~g}$ unit increase in fibre caused at least very large reductions in overall acceptability and flavour for all foods, bread, muffins and cookies (though the uncertainty allowed for trivial to enormous effects). For the acce ptability of texture, a similar pattern was observed except for muffins where large and very large reductions were seen for $5 \mathrm{~g} / 100 \mathrm{~g}$ and $10 \mathrm{~g} / 100 \mathrm{~g}$ unit increase in fibre via supplementation, respectively. Both the 5 $\mathrm{g} / 100 \mathrm{~g}$ and $10 \mathrm{~g} / 100 \mathrm{~g}$ doses were enormously detrimental to appearance.

The analysis provided for a linear estimate of the effect of fibre dose on categorical scores. For every $2 \mathrm{~g} / 100$ addition of fibre, for all foods, bread, muffins, and cookies the mean (0-100 scale) decrease in: overall acceptability was 4.3, 3.6, 3.0, 6.3 units; texture acceptability 3.2, 3.1, 2.1, 4.5; flavor 4.8, 3.7, 3.8, 6.9; and appearance acceptability $7.3,4.7,8.7,8.3$, respectively.

Effect of adding fibre when starting with different basal hedonic scores

Figure 3 presents the effect of altering the baseline acceptability parameter in the basic food (e.g., caused by different food-fibre matrices) on change in acceptability measures when the added dietary fibre value is fixed at $5 \mathrm{~g} / 100 \mathrm{~g}$. With respect to all foods and bread, at lower values for acceptability, $5 \mathrm{~g} / 100 \mathrm{~g}$ fortification increases acceptability scores, however, at higher basic levels 
225 fortification lowered acceptance; in other words the addition of fiber to foods with high acceptability is likely to have a negative effect than foods with lower acceptability. The model also predicted a base point where no change in acceptability will occur with the supplementation of 5 $\mathrm{g} / 100 \mathrm{~g}$ of fibre: $59 \%, 59 \%, 66 \%$, and $75 \%$ for overall acceptability, texture acceptability, flavor acceptability, and appearance acceptability of all foods combined, respectively (Figure 3). Food type differences were represented by steeper gradients for overall acceptability of bread and flavor acceptability of muffins. Cookies presented the most gradual changes in acceptability scores in terms of increasing baseline acceptability values. In the case of acceptability of texture in cookies, lower baseline acceptability values generated negative effects; this was the only food matrix and acceptability measure where this trend was observed.

\section{DISCUSSION}

The main findings of this meta-analysis are that dietary fibre fortification of typical cereal based foods cause substantial reductions in overall acceptability and other food acceptability measures. Cookies were most negatively affected by additional fibre. Fortification of basic non-fortified foods and bread with low acceptability improved acceptance, however, at higher basic levels fortification lowered acceptance. Fortification improved texture acceptability of muffins and bread with low basic acceptability, but lowered texture acceptability when base acceptability was high. Flavor acceptability improvements of muffins with fortification decreased with increasing basic food acceptability. These findings support the conclusions of Mohr et al., (2010) who reported that acceptability of fibre fortification is higher with staple foods as compared to indulgence products. Indeed several researchers have indicated that restricted-range estimates of acceptable levels of fibre supplementation on the textural characteristics of products varies from product to product; for example, pasta 5-10 g/100 g (Tudorica et al., 2002) and extruded snack products 7.5-15 g/100 g (Brennan et al., 2008; Robin et al., 2012). However, these and other point inferences are limited relative to the unique linear dose response estimates provided with the current meta-analysis. Our 
findings provide the first quantitative analysis of the effect of fibre fortification on food acceptability, and show marked differenced and directional effects of fibre between the baked food types examined. Reduced acceptability of fiber-fortified foods could explain low uptake despite health promotion efforts.

The reasons for reduced acceptability due to fibre supplementation can be divided into technical and psychological. Technical are due to the structural changes due the dietary fortification of the food product causing perceptual sensory changes in the food product (Foster et al., 2011). Dietary fibre supplementation is understood to affect the texture and appearance of baked foods technically through the structural changes in the food matrix. High supplementation with dietary fibre is likely to weaken the protein matrix producing well documented effects, such as, reduction of loaf volume, increased crumb firmness and darkening of crumb appearance (Wang et al., 2002; Sangnark \& Noomhorm, 2004a\&b; Liu et al., 2007; Masoodi \& Chauhan, 1998; Clark \& Johnson, 2002; Angioloni \& Collar, 2011). Textural changes in cookies with fibre fortification include increased crumbliness (Laguna et al., 2011), decreased spread value, reduced heights, diameters and increased density (Viera et al., 2008), which are detrimental to overall product acceptability. Therefore, the meta-analysis is consistent with these previous reports, but adds value by providing a linear estimate of the magnitude of change with increasing fibre dose.

Meta-analysis has a number of roles. In addition to creating generalizations, it can also be used to identify key issues for future research (Eisend, 2005). This first meta-analysis on food acceptability data has generated a number of proof-of-concept issues for discussion. The normalization procedures demonstrate the plasticity of the meta-analysis to manage the range of acceptability scales used by the sample of researchers Ten of the 20 trials used the 9 point hedonic scale, whilst other trials used other category and line scales (see Supplementary information). The way subjects rate products is dependent on a number of psychological factors including the type of scale used and 
the information provided in addition to the tasting of the product (Brunso, Fjord, \& Grunert, 2002), but all scales can be reduced to minimum-maximum perception intensity scales. Baixauli et al., (2008b) reported on 102 consumers from the Instituto de Agroquimica y Technologia de Alimentos, Valencia Spain who evaluated the sensory characteristics of a muffin fortified with resistant starch against a wholemeal and plain muffin. Provision of nutritional information significantly increased the overall acceptability for the wholemeal muffins (5.0 to 5.7) compared to no increase for the plain muffins (7.0). The authors grouped the consumers by health conscious attitude and found that overall acceptability was correlated negatively with health consciousness with no label information, but correlated positively when label information when provided. Similar results were reported in a study carried out in Uruguay, where 104 participants were tested via a modified Nutritional Knowledge Questionnaire (Ares, Gimenez, \& Gambaro, 2008). Hierarchical clustering analysis of consumers indicated that consumers can be divided into three clusters based on differing nutritional knowledge with the cluster with the highest nutritional knowledge more willing to try a new fortified fibre functional food. On the other end of the spectrum, the cluster with the least nutritional knowledge were not interested in consuming these fortified products (Ares, Gimenez, \& Gambaro, 2008). Therefore, future research should carefully consider prior knowledge and new information provided to the participants prior to sensory perception evaluation. Another possible methodological concern is cross cultural studies. Mialon et al., (2002) observed significant cultural differences on how people rate wholemeal bread and multigrain muffins using the 9 point hedonic scale (Mialon et al., 2002). Cultural considerations notwithstanding, in the current meta-analysis all study contrasts were internally controlled via the crossover design. Furthermore, inclusion of datasets from multiple ethnic backgrounds, gender, and age make the current results generalizable.

With a greater number of clearly delineated studies and datasets, the effect of these psychological factors (e.g. prior nutritional knowledge, originating country, type of scale) on sensory outcomes can 
be quantified within the meta-analysis. In terms of predicting future outcome of new food product development the meta-analytical conclusions for this type of data presents an opportunity to benchmark consumer affective testing of new innovations in dietary fibre supplementation. In this respect it is worth noting that Baixauli et al., (2008a), Sabinis et al., (2009) and Angiloni et al., (2011) all reported increases in overall acceptability with fibre fortification for specified supplementation levels.

How can more reliable meta-analytical trials in food consumer affective testing be carried out in the future? The majority of studies included in the meta-analysis were focused on New Product Development (NPD) in relation to fibre functionality rather than Consumer insights. As part of any NPD study there is a requirement for consumer feedback (Earle and Earle, 1999) hence there are a large number of sensory trials being reported in the literature to gauge overall acceptability of fibre fortified cereal based products. In this respect acceptability data is being used as a guide in terms of the success of the innovation (Schutz, 1999). Therefore, the majority of these trials were low sample size (only 10 of the trials had 30 panelists or more, and 3 had 100 panelists or more). Pooling of this data and weighting within the meta-analysis, in part, compensates for the low sample size to improve generalizability of outcomes across the population to support the findings of the larger sample consumer trials. However, it is important that researchers should adopt a standardised approach (i.e. a common scale, reporting of precision, significant numbers of appropriately selected untrained consumers for affective testing, appropriate reporting of demographics of those consumers tested, and appropriate application and reporting of standard sensory procedures). Only one trial reported in this meta-analysis (Baixauli et al., 2008a) used a combination of trained panelists for generation and measure of attribute intensity and consumer panel for measure of acceptance. This approach gives a sound methodological approach for understanding more fully the sensory drivers of acceptance as opposed to just focusing on consumer hedonic testing. Finally, the analytical calculation of the dietary fibre composition may also be a source of methodological concern. There 
are distinct differences in the types of fibres measured by different types of dietary fibre tests. In this study the main methods used was the official total dietary fibre methods of the Association of Official Analytical Chemists (AOAC) and the American Association of Cereal Chemists AACC. This allows for the analysis of all non digestible carbohydrates (including resistant starch and soluble fibre sources) plus lignin and is likely to generate the highest absolute numerical value for dietary fibre reporting of fortified products. However, there were exceptions in the studies used for the meta-analysis. Two authors used non-referenced manufacturers data of dietary fibre analysis (Baixauli et al., 2008b, Mialon et al., 2002), while others use cellulose (Uysal et al., 2007), resistant starch (Baixauli et al., 2008a) and neutral detergent fibre analysis (Masoodi, 1998) as a measure of fortification levels which may all lead to lower dietary fibre values than the official AOAC method. The call for a standardisation approach for measuring dietary fibre and the potential adoption of the AOAC total dietary fibre method as the standard method (Butriss \& Stokes, 2008) will support more accurate future comparative studies and accumulative analyses.

\section{CONCLUSION}

This study demonstrates the utility of a meta-analytical approach in gaining valid unbiased new insight into understanding responses to fibre fortification in foods. Dietary fibre supplementation cause moderate to extremely large reductions in the overall food acceptability response on baked goods when evaluating the response using a meta-analysis on 20 eligible studies. Cookies were most negatively affected by additional fibre. Basic food acceptability determined the response to fortification: bread with low acceptability was improved, whereas the opposite was observed with high acceptability. The texture acceptability of muffins and bread with low basic acceptability was improved with fortification but lowered when base acceptability was high. Flavor improvement of muffins with fortification decreased with increasing basic food acceptability. Our findings provide the first quantitative analysis of the effect of fibre fortification on food acceptability responses with information that could be relevant towards optimizing fortification fibre dose for increased public 
uptake. A second categorical finding of the current work is derived from assessment of the divergent approaches in sensory analysis. We recommend adoption of a standardized approach to quantitative consumer trials to improve consumer sensory studies.

358

359 Acknowledgement. Prof Will G. Hopkins for assistance with the meta-analysis. Author contributions 360 were: John Grigor conceived the analysis, conducted the primary literature search, and wrote the 361 paper; David Rowlands developed and ran the meta-analysis, wrote the paper, developed the figures 362 and tables, managed publication processes; Scott Hutchings conducted secondary and confirmatory 363 literature search and data compilation; Charles Brennan reviewed, revised and proofed the 364 manuscript. 
Abdul-Hamid, A., \& Luan, Y. S. (2000). Functional properties of dietary fibre prepared from defatted rice bran. Food Chemistry, 68, 15-19.

370

Acosta, K., Cavender, G. \& Kerr, W.L. (2011). Sensory and physical properties of muffins made with

Angioloni, A. \& Collar C. (2011). Physicochemical and nutritional properties of reduced-caloric density high-fibre breads. LWT-Food Science and Technology, 44, 747-758. healthiness and willingness to try functional foods. Appetite, 51, 663-668.

Asp, N.G., Johansson, C.G., Hollmer, H., \& Siljestram, M (1983). Rapid enzymatic assay of insoluble and soluble dietary fibre. Journal of Agricultural and Food Chemistry, 33, 476-482.

382

Aziah, N.A.A., Ho, L. H., , Shazliana, N.A.A., \& Bhat, R. (2012). Quality evaluation of steamed wheat bread substituted with green banana flour. International Food Research Journal 19, 869-876.

Bagheri, R. and Seyedein, S.M. (2011). The effect of adding rice bran fibre on wheat dough performance and bread quality, World Applied Sciences Journal, 14,121-125 
Preference, 19, 628-635.

395

396

Bangoura, M. L., Nsor-Atindana, J., Zhu, K., Tolno, M. B., Zhou, H. \& Wei, P. (2013).

397

Potential hypoglycaemic effects of insoluble fibres isolated from foxtail millets [Setaria

italica (L.) P. Beauvois]. International Journal of Food Science \& Technology, 48, 496-502.

399

400

Barker, M. E., Thompson, K. A., \& McClean, S. I. (1995). Attitudinal dimensions of food choice and

nutrient intake. British Journal of Nutrition, 74, 649-659.

402

Brennan, M., Monro, J. A. \& Brennan, C. S. (2008). Effect of inclusion of soluble and insoluble fibres

into extruded breakfast cereal products made with reverse screw configuration. International

Journal of Food Science and Technology, 43, 2278-2288.

406

407

Brunsø, K., Fjord, T. A., \& Grunert, K. G. (2002). Consumers' food choice and quality perception.

MAPP working paper 77. Aarhus: Aarhus School of Business.

409

410

Butriss, J.L., \& Stokes, C.S.(2008). Dietary fibre and health: an overview. British Nutrition Foundation

Nutrition Bulletin 33, 186-200.

412

Clark, R., \& Johnson, S. (2002). Sensory acceptability of foods with added lupin (Lupinus angustifolius) kernel fiber using pre-set criteria. Journal of Food Science, 67, 356-362.

416 Cohen, J. (1988) Statistical power analysis for the behavioural sciences, Lawrence Erlbaum, Hillsdale, NJ. 
Dhingra, S., \& Jood, S. (2001). Organoleptic and nutritional evaluation of wheat breads supplemented with soybean and barley flour. Food Chemistry, 77, 479-488.

421

Earle, M. \&. Earle, R. (1999). Creating New Foods: A Product Developer's Guide. Chandos Publishing

(Oxford) Ltd, Oxford, England.

424

Eisend, M. (2005), The role of meta-analysis-in marketing and consumer behavior research:

stimulator or inhibitor ? Advances in Consumer Research, 32, 620-622.

427

EU consumer attitudinal survey. In: Institute-of-European-Food-Studies Workshop on Food-Based

Dietary Guidelines - A Staged Approach (pp. S133-S137). Dublin, Ireland: C a B International.

430

Food Standards Agency, 2014. National Diet and Nutrition Survey. Results from Years 1, 2, 3 and 4

(combined) of the Rolling Programme (2008/2009 2011/2012) 2, Public Health England Wellington

House 133-155 Waterloo Road London SE1 8UG.

434

Foster, K.D., Grigor, J.M.V., Cheong, J.N., Yoo, M.J.Y., Bronlund, J.E. \& Morgenstern, M.P. (2011). The

Frewer, F Scholderer, J. \& Lambert, N. (2003). Consumer acceptance of functional foods: issues for the future. British Food Journal, 105(10), $714-73$.

Gélinas, P. (2013). Preventing constipation: a review of the laxative potential of food ingredients. International Journal of Food Science and Technology, 48, 445-467 

substitution with flaxseed on quality and functionality of injera. Journal of Food Science and Technology, 48, 350-356.

447

Gupta, M., Bawa, A.S. \& Abu-Ghannam, N.(2011). Effect of barley flour and freeze-thaw cycles on 527.

Hall, R.S., Baxter, A.L., Fryirs, C., \& Johnson, S.K. (2010). Liking of health-functional foods containing lupin kernal fibre following repeated consumption in a dietary intervention setting. Appetite, 55, 232-237

Haque, M.A., Shams-Ud-Din, M. and Haque A. (2002). The effect of aqueous extracted wheat bran on the baking quality of biscuits. International Journal of Food Science and Technology 37, 453-462

Hopkins, W. G. (2002) Effect statistics: a scale of magnitudes for effect statistics. Vol. 2007,

Ho, L-H, Aziz, N.A.A, \& Azahari, B. (2013). Physico-chemical characteristics and sensory evaluation of wheat bread partially substituted with banana (Musa acuminata X balbisiana cv. Awak) pseudo-stem flour. Food Chemistry, 139(1-4), 532-539. Australian sweet lupin (Lupinus angustifolius) kernel fibre and its glycaemic and insulinaemic 
Kearney, J. M., \& McElhone, S. (1998). Perceived barriers in trying to eat healthier - results of a pan-

471 EU consumer attitudinal survey. In: Institute-of-European-Food-Studies Workshop on Food-Based

Laguna, L., Salvador, A., Sanz, T. \& Fiszman, M. (2011). Performance of a resistant starch rich

Lawless, H.T., \& Heymann, H. (1999). Sensory evaluation of foods: principles and practices. Aspen

Publication, Gathersburg, Maryland.

480

Lebesi, D.M. \& Tzia, C. (2011). Effect of the addition of different dietary fiber and edible cereal bran sources on the baking and sensory characteristics of cupcakes, Food and Bioprocess Technology, 4(5), 710-722.

Liu, L. Y., Wu, K. L., Jen, Y. W., \& Yang, M. H. (2007). Effect of sweet potato leaf and stem addition on dough properties and bread quality. Food Science and Technology International, 13, 239-244.

487

Masoodi, F.A. \& Chauhan, G.S.(1998). Use of apple pomace as a source of dietary fibre in wheat bread. Journal of Food Processing and Preservation, 22, 255-263.

490

Maziarz, M., Sherrard, M., Juma, S., Prasad, C., Imrhan, V. \& Vijayagopal. (2013). Sensory characteristics of high-amylose maize-resistant starch in three products, Food Science \& Nutrition, 1(2), 117-124. 
Mildner-Szkudlarz, S., Bajerska, J., Zawirska-Wojtasiak, R., \& Gorecka, D. (2013). White grape pomace as a source of dietary fibre and polyphenols and its effect on physical and nutraceutical

Mohr, P., Quinn, S., Morell, M., \& Topping, D. (2010). Engagement with dietary fibre and

Murphy, N., T. Norat, P. Ferrari, M. Jenab, B. Bueno-de-Mesquita, G. Skeie, C. C. Dahm, K. Overvad, Boeing, M. M. Bergmann, A. Trichopoulou, D. Trichopoulos, P. Lagiou, D. Palli, V. Pala, S. Panico, R.

Gonzalez, M. J. Sanchez, M. Dorronsoro, C. Navarro, E. Ardanaz, J. R. Quiros, E. Sonestedt, U. Ericson, Chuang and E. Riboli (2012). Dietary fibre intake and risks of cancers of the colon and rectum in the European prospective investigation into cancer and nutrition (EPIC). PLoS One 7(6), e39361.

Ng, S. H. \& Wan Rosli, W. L. (2013). Effect of cornsilk (Maydis stigma) addition in yeast bread: investigation on nutritional compositions, textural properties and sensory acceptability. International Food Research Journal 20, 339-345. 
522

523

524

525

526

527

528

529

530

531

532

533

534

535

536

537

538

539

540

541

542

543

544

physico-chemical properties, antioxidant capacity and application as bakery product ingredients. Malaysian Journal of Nutrition ${ }_{2}$ 19, 99-109.

Papathanasopoulos, A. and M. Camilleri (2010). Dietary Fiber Supplements: Effects in Obesity and Metabolic Syndrome and Relationship to Gastrointestinal Functions. Gastroenterology 138(1), 65-72.

Robin, S., Schuchmann, S.P. \& Palzer, S.(2012). Dietary fiber in extruded cereals: limitations and opportunities. Trends in Food Science and Technology, 28, 23-32.

Sabanis, D., Lebesi, D. \& Tzia.(2009). Effect of dietary fibre enrichment on selected properties of gluten-free bread. LWT-Food Science and Technology, 42, 1380-1389.

Sangnark, A., \& Noomhorm, A. (2004a). Chemical, physical and baking properties of dietary fiber prepared from rice straw. Food Research International, 37, 66-74.

Sangnark, A., \& Noomhorm, A. (2004b). Effect of dietary fiber from sugarcane bagasse and sucrose ester on dough and bread properties. Lebensmittel-Wissenschaft und-Technologie, 37, 697-704.

Schutz, H,G. (1999). Consumer data-sense and nonsense. Food Quality and Preference, 10, 245-251.

Šeremešić, M.M., Dokić, L., Nicolić, I., Radosavljević, M. \& Simović, D.S.(2013). Rheological and textural properties of short (cookie) dough made with two types of resistant starch, Journal of Texture Studies, 44, 115-123.

Sharma, C., Punia, D., \& Khetarpaul, N. (2013). Sensory characteristics, proximate composition, dietary fibre content and storage stability of barley, wheat and chickpea composite flour biscuits. 
Slavin, J.L. (2008). Position of the American Dietetic Association: health implications of dietary fibre. Journal of the American Dietetic Association, 108(10), 1716-1731.

550

Snyder, B. (2008). Health communication campaigns and their impact on behavior. Journal of Nutrition and Education Behaviour, 39, S32-S40.

553

Threapleton, D.E., Greenwood, D.C., Evans, C.E.L., Cleghorn, C.L., Nykjaer, C., Woodhead, C., Cade, systematic review and meta-analysis. British Medical Journal, 347:f6879.

557

558

Torres, A., Frias, j, Granito, M., Guerra, M., \& Vidal-Valverde, C. (2007). Chemical, biological and sensory evaluation of pasta products supplemented with alpha-galactoside-free lupin flours. Journal of the Science of Food and Agriculture, 87, 74-81.

561

Tudorică, C.M., Kuri ,V., Brennan, C.S.(2002). Nutritional and physicochemical characteristics of dietary fiber enriched pasta. Journal of Agricultural and Food Chemistry, 50 (2), 347-356.

564

Urooj, A., Vinutha, S. R., Puttaraj, S., Leelavathy, K., \& Rao, P. H. (1995). Effect of barley incorporation in bread on its quality and glycemic responses in diabetics. In: National Conference of the Indian-Dietetic-Association (pp. 265-270). Bombay, India: Carfax Publ Co. 
573 Uysal, H., Bilgicli, N., Elgun, A., İbanoğlu, S., Herken, E. N., \& Demir, M. K. (2007). Effect of dietary

574 fibre and xylanase enzyme addition on the selected properties of wire-cut cookies. Journal of Food 575 Engineering, 78, 1074-1078.

576

577 Verbeke, W. (2006). Functional foods: consumer willingness to compromise on taste for health? Food Quality and Preference, 17, 126-131.

579

580 Vieira, M.A., Tramonte, K.C., Podestá, R., Avancini, S.R.P., Amboni, R.D. de M. C. \& Amante, R. 581 (2008). Physicochemical and sensory characteristics of cookies containing residue from king palm 582 (Archontophoenix alexandrae) processing. International Journal of Food Science and Technology, 43, $583 \quad 1534-1540$.

584

Wang, J., Rosell, C. M., \& Benedito de Barber, C. (2002). Effect of the addition of different fibres on 586 wheat dough performance and bread quality. Food Chemistry, 79, 221-226.

587

588

Waters, D.M., Jacob, F., Titze, J., Arendt, E.K. \& Zannini, E.(2012). Fibre, protein and mineral 589 fortification of wheat bread through milled and fermented brewer's spent grain enrichment, European Food Research and Technology, 235(5), 767-778.

591

592 Yadav, D., Krishna, K. \& Rehal, J.(2012). Studies on fortification of wheat flour with defatted rice bran 593 for chapatti making. Journal of Food Science and Technology, 49(1), 96-102. 


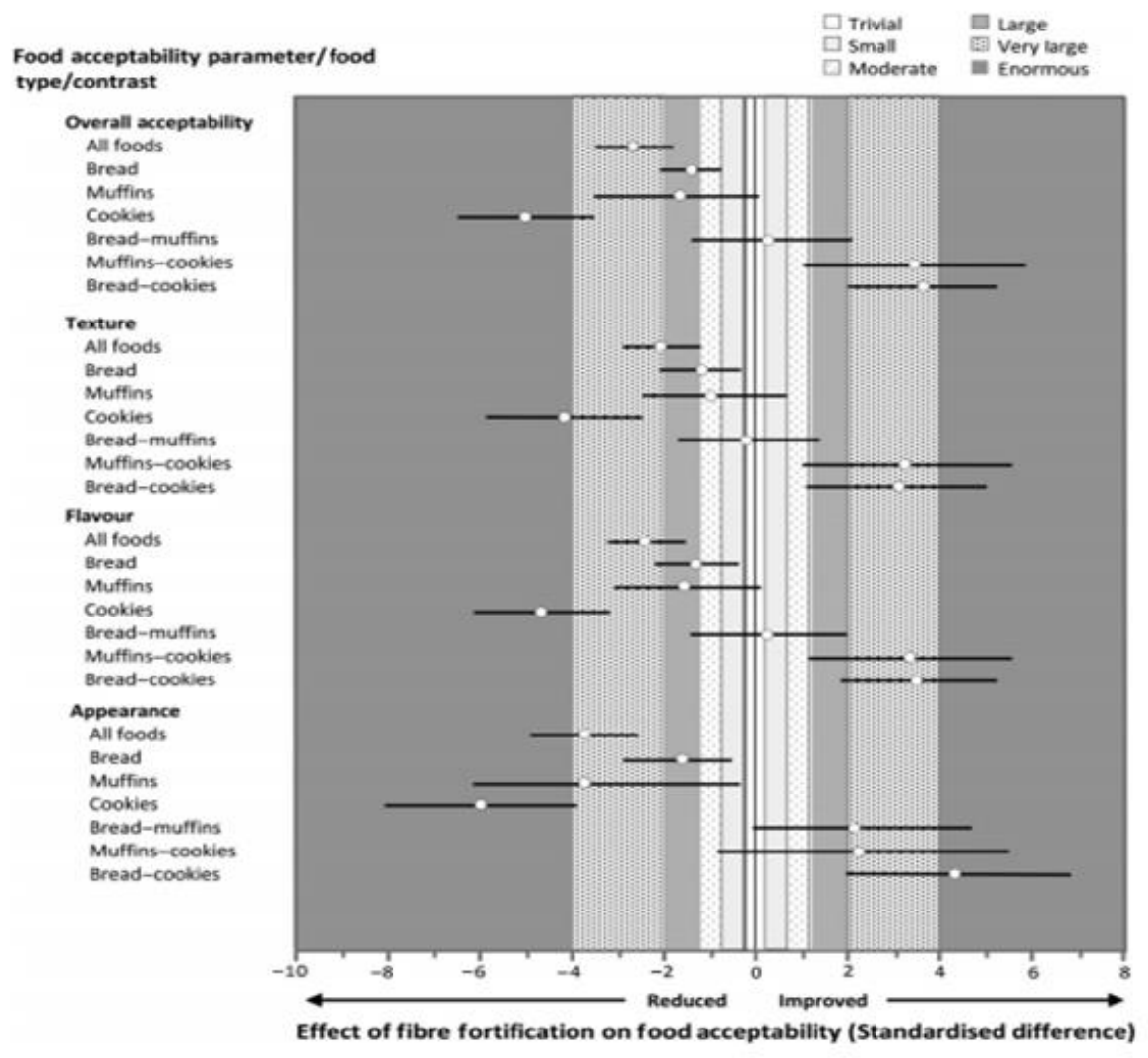

Figure 1. Effect of fibre fortification on food acceptability. Shown is the estimated large-sample population response to the effect of the meta-analyzed mean fibre quantity on food acceptability ratings for all foods, bread muffins, and cookies, and for the respective differences in the response between food types. Data are the standardised mean responses with $95 \%$ confidence interval. Effect magnitude (standardized difference) is displayed in the background defined by the legend key. 

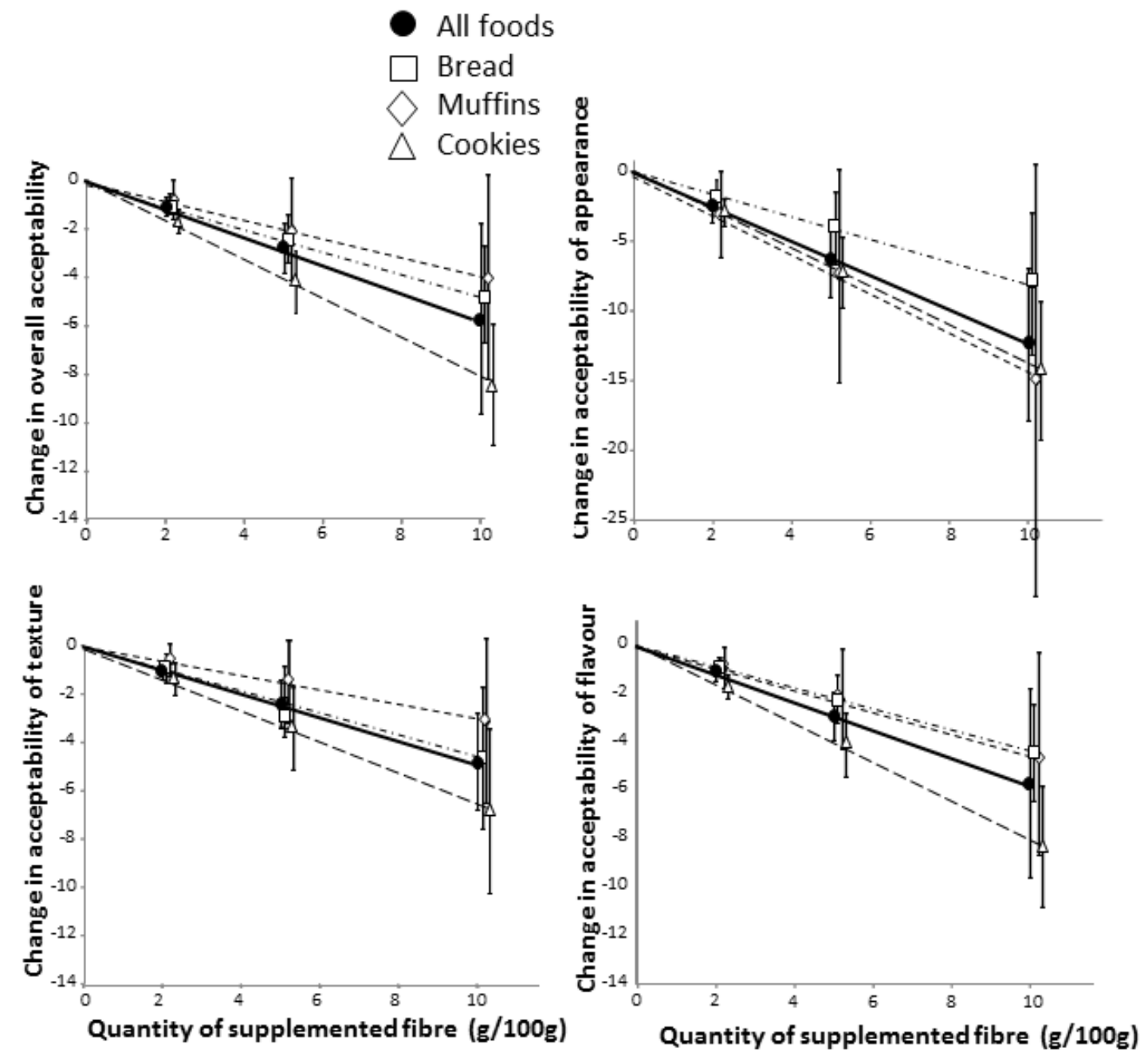

606

607

Figure 2. Effect of graded addition of fibre fortification on food acceptability, relative to the meta

608 analytical baseline non-fortified control food. Shown are the estimated population response to

609 added fibre quantity on food acceptability ratings for all foods, bread, muffins, and cookies. Point data are the standardised change in acceptability parameter with $95 \%$ confidence interval. 

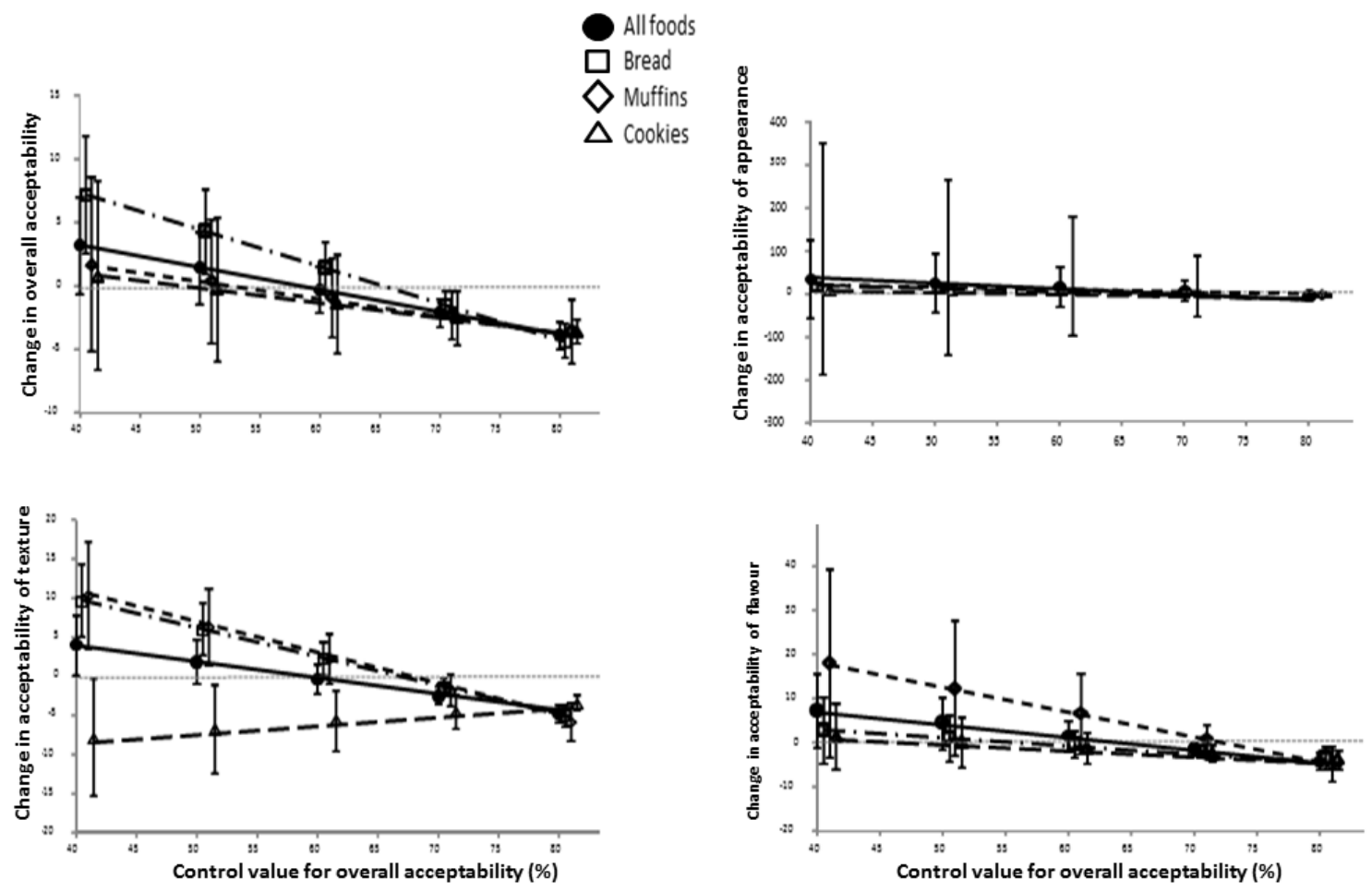

614 Figure 3. Magnitude and direction of change in food acceptability depending upon the baseline value

615 for acceptability. Shown are the estimated population response to the addition of $5 \mathrm{~g}$ per $100 \mathrm{~g}$ of

616 fibre on food acceptability ratings for all foods, bread, muffins, and cookies. Point data are the

617 standardised change in acceptability parameter with 95\% confidence interval.

Table 1. Food, fortified fibre, and sample characteristics of the studies included within the metaanalysis.

\begin{tabular}{|c|c|c|c|c|c|}
\hline Author & Year & Food & Fibre type & $\begin{array}{l}\mathbf{n} \\
\text { (fraction maleness } \\
\text { where reported) }\end{array}$ & Panel $^{\mathrm{a}}$ \\
\hline Urooj et al. & 1998 & Bread & $\begin{array}{l}\text { Pearled barley } \\
\text { Whole barley }\end{array}$ & $15(0.47)$ & People with diabetes (UT) \\
\hline Masoodi \& Chauhan & 1998 & Bread & Apple pomace & 10 & $\begin{array}{l}\text { Laboratory panel of judges } \\
\text { (T) }\end{array}$ \\
\hline Abdul-Hamid \& Luan & 2000 & Bread & $\begin{array}{l}\text { Defatted rice bran } \\
\text { Fibrex (commercial } \\
\text { fibre source) }\end{array}$ & 30 & $\begin{array}{l}\text { University employee or } \\
\text { students }(T)\end{array}$ \\
\hline Clark \& Johnson & 2002 & Bread & Lupin kernal fibre & $44(0.34)$ & University employee or \\
\hline
\end{tabular}




\begin{tabular}{|c|c|c|c|c|c|}
\hline \multirow[b]{2}{*}{ Mialon et al. } & \multirow[b]{2}{*}{2002} & \multicolumn{3}{|l|}{ Muffins } & \multirow{2}{*}{$\begin{array}{l}\text { students (UT) } \\
\text { Bread consumers } \\
\text { (Malaysians, Australians) (UT) }\end{array}$} \\
\hline & & $\begin{array}{l}\text { Bread } \\
\text { Muffins }\end{array}$ & $\begin{array}{l}\text { Wholemeal Enriched } \\
\text { fibre, Multigrain }\end{array}$ & $779(0.48), 82$ & \\
\hline Wang et al. & 2002 & Bread & $\begin{array}{l}\text { Carob fibre, Inulin } \\
\text { Pea fibre }\end{array}$ & $15(0.33)$ & Trained panelists $(T)$ \\
\hline Johnson et al & 2003 & Bread & Lupin kernel fibre & $54(0.15)$ & $\begin{array}{l}\text { University employee or } \\
\text { students (UT) }\end{array}$ \\
\hline Uysal et al. & 2007 & Cookies & $\begin{array}{l}\text { Apple fibre, Lemon } \\
\text { fibre, Wheat fibre } \\
\text { Wheat bran }\end{array}$ & 7 & Untrained panelists (UT) \\
\hline Baixauli et al. & $2008 a$ & Muffins & Resistant starch & $50(0.5)$ & $\begin{array}{l}\text { Employees of the University } \\
\text { (UT) }\end{array}$ \\
\hline Baixauli et al. & $2008 b$ & Muffins & Resistant starch & $102(0.32)$ & $\begin{array}{l}\text { University employee or } \\
\text { students (UT) }\end{array}$ \\
\hline Vieira et al. & 2008 & Cookies & $\begin{array}{l}\text { King palm residue } \\
\text { fibre }\end{array}$ & 100 & Habitual cookie consumer(UT) \\
\hline Sabanis et al. & 2009 & Bread & $\begin{array}{l}\text { Wheat fibre, Maize } \\
\text { fibre, Oat fibre, } \\
\text { Barley fibre }\end{array}$ & 10 & $\begin{array}{l}\text { Trained in sensory analysis } \\
\text { lexicon and methodology }(\mathrm{T})\end{array}$ \\
\hline Laguna et al. & 2011 & Cookies & Resistant starch & $103(0.25)$ & $\begin{array}{l}\text { Untrained frequent biscuit } \\
\text { consumers(UT) }\end{array}$ \\
\hline Angioloni \& Collar & 2011 & Bread & $\begin{array}{l}\text { Carboxymethyl } \\
\text { cellulose/locust } \\
\text { bean gum and } \\
\text { oligosaccharides }\end{array}$ & $8(0.5)$ & Trained panelists $(\mathrm{T})$ \\
\hline $\begin{array}{l}\text { Aziah, Ho, Shazliana, } 8 \\
\text { Bhat }\end{array}$ & 2012 & Bread & Green banana flour & 35 & $\begin{array}{l}\text { Trained panelists from the } \\
\text { University }(T)\end{array}$ \\
\hline $\begin{array}{l}\text { Mildner-Szkudlarz et } \\
\text { al. }\end{array}$ & 2012 & Cookies & White grape pomace & 10 & Trained panelists $(\mathrm{T})$ \\
\hline Ho, Aziz, \& Azahari & 2013 & Bread & $\begin{array}{l}\text { Banana pseudo- } \\
\text { steam flour Xanthan } \\
\text { gum Carboxymethyl } \\
\text { cellulose }\end{array}$ & 30 & $\begin{array}{l}\text { Semi-trained panelists from } \\
\text { Department of Food Science } \\
\text { and Technology }(T)\end{array}$ \\
\hline Ng \& Rosli & 2013 & Bread & Corn silk powder & $60(0.33)$ & $\begin{array}{l}\text { University employee or } \\
\text { students (UT) }\end{array}$ \\
\hline Nyam, Lau, \& Tan & 2013 & Bread & $\begin{array}{l}\text { Pumpkin seed and } \\
\text { Pumpkin Rind }\end{array}$ & $15(0.47)$ & Trained panelists $(T)$ \\
\hline $\begin{array}{l}\text { Sharma, Punia, \& } \\
\text { Khetarpaul }\end{array}$ & 2013 & Cookies & $\begin{array}{l}\text { Barly flour Chickpea } \\
\text { flour }\end{array}$ & $10(0.0)$ & $\begin{array}{l}\text { University employee or } \\
\text { students semi trained (T) }\end{array}$ \\
\hline
\end{tabular}

620

621

622 
Table 2. Meta-analysed mean (standard deviation) baseline control fiber data for control food items and the effect of fibre fortification on mean sensory acceptability response.

\begin{tabular}{|c|c|c|c|c|}
\hline Food & $\begin{array}{l}\text { Control food } \\
\text { fibre }^{1}\end{array}$ & $\begin{array}{l}\text { Control food } \\
\text { Acceptability } \\
\text { score }^{2}\end{array}$ & $\begin{array}{l}\text { Fibre } \\
\text { fortification }^{1}\end{array}$ & $\begin{array}{l}\text { Sensory response to } \\
\text { fibre fortification }^{3}\end{array}$ \\
\hline & \multicolumn{4}{|c|}{ Overall Acceptability } \\
\hline All foods & $2.9(2.0)$ & 75.3 (9.5) & $4.1(2.7)$ & $-8.8(15.0)$ \\
\hline Bread & $2.4(0.7)$ & $72.1(7.4)$ & $3.5(1.7)$ & $-4.3(12.0)$ \\
\hline Muffins & $4.5(1.9)$ & $66.8(10.9)$ & $3.4(2.0)$ & $-2.6(4.6)$ \\
\hline \multirow[t]{2}{*}{ Cookies } & $3.3(3.0)$ & $84.1(4.9)$ & $5.4(3.8)$ & $-19.0(17.5)$ \\
\hline & \multicolumn{4}{|c|}{ Texture Acceptability } \\
\hline All foods & $3.0(2.5)$ & $74.1(7.8)$ & $4.3(3.1)$ & $-6.7(15.5)$ \\
\hline Bread & $2.2(0.5)$ & $71.6(7.4)$ & $3.1(1.7)$ & $-1.8(11.6)$ \\
\hline Muffins & $5.5(2.0)$ & $68.3(7.7)$ & $4.5(1.7)$ & $3.9(9.6)$ \\
\hline \multirow[t]{2}{*}{ Cookies } & $3.4(3.6)$ & $79.6(4.9)$ & $6.0(4.2)$ & $-17.2(16.6)$ \\
\hline & \multicolumn{4}{|c|}{ Flavour Acceptability } \\
\hline All foods & $3.1(2.3)$ & $74.5(7.2)$ & $4.2(3.0)$ & $-9.0(16.1)$ \\
\hline Bread & $2.5(0.7)$ & $70.6(7.3)$ & $3.2(1.7)$ & $-4.2(9.4)$ \\
\hline Muffins & $5.5(2.0)$ & $74.2(3.1)$ & $4.5(1.7)$ & $-1.5(6.4)$ \\
\hline \multirow[t]{2}{*}{ Cookies } & $3.4(3.6)$ & $81.9(4.1)$ & $6.0(4.2)$ & $-20.4(21.8)$ \\
\hline & \multicolumn{4}{|c|}{ Appearance Acceptability } \\
\hline All foods & $2.7(1.8)$ & $77.4(12.3)$ & $4.4(3.1)$ & $-13.0(22.7)$ \\
\hline Bread & $2.4(0.7)$ & $79.8(14.7)$ & $3.4(1.7)$ & $-7.3(20.7)$ \\
\hline Muffins & $5.5(2.0)$ & $80.7(0.6)$ & $4.5(1.7)$ & $-9.5(10.0)$ \\
\hline Cookies & $2.2(2.3)$ & $83.1(5.0)$ & $6.2(4.6)$ & $-25.4(25.8)$ \\
\hline
\end{tabular}

${ }^{1} \mathrm{~g} / 100 \mathrm{~g}$ of fibre.

${ }^{2}$ Baseline control sensory response expressed as percent on the normalized 0-100 scale.

${ }^{3}$ Change in acceptability scale in response to meta-mean fibre fortification on the normalized 0 100 scale.

624

625

626 
Supplementary Table. Compiled study fibre dose and acceptability data.

\begin{tabular}{|c|c|c|c|c|c|c|c|}
\hline Study & Date & $\begin{array}{l}\text { Total Dietary } \\
\text { Fibre Dose } \\
\mathrm{g} / 100 \mathrm{~g} \\
\mathrm{C}=\text { control }\end{array}$ & $\begin{array}{l}\text { Type of } \\
\text { Acceptability Scale }\end{array}$ & $\begin{array}{l}\text { Texture } \\
\text { acceptability }\end{array}$ & $\begin{array}{l}\text { Flavour } \\
\text { acceptability }\end{array}$ & $\begin{array}{l}\text { Appearance } \\
\text { acceptability }\end{array}$ & Overall Acceptability \\
\hline Urooj A et al & 1998 & $\begin{array}{l}3.3 \mathrm{C} \\
6.7 \\
8.5\end{array}$ & $\begin{array}{l}6 \text { point categorical } \\
\text { scale }(1=\text { very } \\
\text { unpleasant to } 6= \\
\text { very pleasant) }\end{array}$ & . & . & . & $\begin{array}{l}5.1 \\
4.1 \\
3.4\end{array}$ \\
\hline $\begin{array}{l}\text { Masoodi \& } \\
\text { Chauhan }\end{array}$ & 1998 & $\begin{array}{l}1.9 \mathrm{C} \\
2.39 \\
3.69 \\
4.32 \\
7.07\end{array}$ & $\begin{array}{l}\text { Grading score } \\
\text { Acceptability rating } \\
\text { based on score card } \\
\text { ( } 5 \text { grades= poor, } \\
\text { fair, satisfactory, } \\
\text { good, excellent) }\end{array}$ & $\begin{array}{l}17.6 \text { ( out of } 20) \\
16.8 \\
14.4 \\
13.1 \\
10.5\end{array}$ & $\begin{array}{l}19.8 \text { (out of 25) } \\
15.5 \\
17.3 \\
15.7 \\
13.5\end{array}$ & $\begin{array}{l}21.8 \text { (out of 25) } \\
18.4 \\
15.1 \\
11.7 \\
11\end{array}$ & $\begin{array}{l}86.1 \text { (out of 100) } \\
79.6 \\
68.3 \\
58 \\
50.8\end{array}$ \\
\hline $\begin{array}{l}\text { Abdul-Hamid \& } \\
\text { Luan }\end{array}$ & 2000 & $\begin{array}{l}1.61 \mathrm{C} \\
4.67 \\
8.24 \\
4.32 \\
8.17\end{array}$ & $\begin{array}{l}9 \text { point hedonic } \\
\text { categorical scale } \\
\text { (1=dislike } \\
\text { extremely to } 9=\text { like } \\
\text { extremely) }\end{array}$ & $\begin{array}{l}6.73 \\
6.4 \\
6 \\
6.27 \\
5.9\end{array}$ & $\begin{array}{l}6.8 \\
6.0 \\
5.0 \\
6.03 \\
5.13\end{array}$ & $\begin{array}{l}7.47 \\
6.4 \\
5.2 \\
6.47 \\
4.9\end{array}$ & $\begin{array}{l}7.2 \\
6.3 \\
5.3 \\
6.3 \\
4.8\end{array}$ \\
\hline Clark \& Johnson & 2002 & $\begin{array}{l}2.8 \mathrm{C} \text { (bread) } \\
6.5 \\
1.4 \mathrm{C} \text { (muffin) } \\
5.4\end{array}$ & $\begin{array}{l}15 \mathrm{~cm} \text {, 7-point } \\
\text { structured graphic } \\
\text { hedonic scale (left } \\
\text { anchor=dislike } \\
\text { extremely, right } \\
\text { anchor =like } \\
\text { extremely) }\end{array}$ & $\begin{array}{l}11.11 \\
11.33 \\
11.81 \\
10.83\end{array}$ & $\begin{array}{l}11.43 \\
11.11 \\
11.79 \\
10.6\end{array}$ & $\begin{array}{l}11.95 \\
11.03 \\
11.99 \\
12.08\end{array}$ & $\begin{array}{l}11.5 \\
11.5 \\
12.2 \\
10.9\end{array}$ \\
\hline Mialon et al. & 2002 & $\begin{array}{l}1.9 \mathrm{C} \text { (bread) } \\
6.5 \\
5.7 \\
3.1 \mathrm{C} \text { (muffin) } \\
4.5 \\
4.9 \\
1.9 \mathrm{C} \text { (bread) } \\
6.5 \\
5.7 \\
3.1 \mathrm{C} \text { (muffin) } \\
4.5 \\
4.9\end{array}$ & $\begin{array}{l}15 \mathrm{~cm} \text { unstructured } \\
\text { hedonic line scale } \\
\text { (scale anchors= } \\
\text { dislike extremely to } \\
\text { like extremely) }\end{array}$ & $\begin{array}{l}. \\
. \\
. \\
. \\
. \\
. \\
. \\
. \\
. \\
.\end{array}$ & $\begin{array}{l}. \\
. \\
. \\
. \\
. \\
. \\
. \\
. \\
. \\
.\end{array}$ & $\begin{array}{l}\dot{ } \\
\dot{.} \\
. \\
. \\
. \\
. \\
. \\
. \\
. \\
. \\
.\end{array}$ & $\begin{array}{l}6.3 \text { (Malaysian consumers) } \\
5.6 \\
5.8 \\
4.4 \\
4.1 \\
4.1 \\
7.2 \text { (Australian consumers) } \\
5.6 \\
6.7 \\
5.7 \\
5.3 \\
5.5\end{array}$ \\
\hline Wang et al. & 2002 & $\begin{array}{l}3 \mathrm{C} \\
5.1 \\
5.1 \\
5.4\end{array}$ & $\begin{array}{l}9 \text { point hedonic } \\
\text { categorical scale } \\
\text { (1=dislike } \\
\text { extremely to } 9=\text { like } \\
\text { extremely) }\end{array}$ & $\begin{array}{l}6.2 \\
6.3 \\
5.2 \\
5.9\end{array}$ & $\begin{array}{l}7.1 \\
5.7 \\
6.7 \\
6.4\end{array}$ & $\begin{array}{l}. \\
. \\
.\end{array}$ & $\begin{array}{l}6.8 \\
6.1 \\
6.3 \\
6.1\end{array}$ \\
\hline Johnson et al. & 2003 & $\begin{array}{l}3.5 \mathrm{C} \\
6.6 \\
8.3\end{array}$ & $\begin{array}{l}15 \mathrm{~cm} \text { descriptive } \\
\text { anchored line scale } \\
\text { (Anchors for } \\
\text { appearance, flavour } \\
\text { and texture= dislike } \\
\text { extremely to like } \\
\text { extremely. Anchor } \\
\text { for overall } \\
\text { acceptability = } \\
\text { highly unacceptable }\end{array}$ & $\begin{array}{l}10.16 \\
9.96 \\
9.75\end{array}$ & $\begin{array}{l}9.01 \\
8.94 \\
8.27\end{array}$ & $\begin{array}{l}10.87 \\
9.9 \\
8.69\end{array}$ & $\begin{array}{l}10.28 \\
9.66 \\
9.29\end{array}$ \\
\hline
\end{tabular}




\section{to highly}

acceptable

\begin{tabular}{|c|c|c|c|c|c|c|c|}
\hline \multirow[t]{13}{*}{ Uysal et al. } & \multirow[t]{13}{*}{2007} & $1.14 \mathrm{C}$ & \multirow{2}{*}{$\begin{array}{l}5 \text { point hedonic } \\
\text { categorical scale }\end{array}$} & \multirow{2}{*}{$\begin{array}{l}3.9 \\
3.6\end{array}$} & \multirow{2}{*}{$\begin{array}{l}4 \\
2.9\end{array}$} & \multirow{2}{*}{$\begin{array}{l}4.3 \\
2.3\end{array}$} & \multirow{2}{*}{$\begin{array}{l}4.3 \\
3.4\end{array}$} \\
\hline & & 3.04 & & & & & \\
\hline & & 3.97 & (1=dislike & 3.4 & 2.5 & 2.1 & 2.9 \\
\hline & & 4.78 & extremely, & 2.7 & 2 & 1.9 & 2.2 \\
\hline & & 7.12 & 3=acceptable, & 1.8 & 2 & 2.3 & 2.1 \\
\hline & & 8.61 & 5=like extremely) & 1.3 & 1.4 & 1.9 & 1.5 \\
\hline & & 12.92 & & 1.1 & 1.1 & 1.5 & 1.1 \\
\hline & & 8.44 & & 3.1 & 2.5 & 2.5 & 2.8 \\
\hline & & 11.71 & & 2.8 & 2.3 & 1.9 & 2.5 \\
\hline & & 17.69 & & 2.4 & 2.2 & 1.5 & 2.2 \\
\hline & & 1.75 & & 3.8 & 3.7 & 3.7 & 3.9 \\
\hline & & 1.76 & & 3.6 & 3.7 & 3.5 & 3.8 \\
\hline & & 2.39 & & 3.3 & 3.5 & 3.3 & 3.5 \\
\hline \multirow[t]{5}{*}{ Baixauli et al. } & \multirow[t]{5}{*}{$2008 a$} & $6.3 \mathrm{C}$ & 9 point hedonic & 5.7 & 6.5 & 7.3 & 6.4 \\
\hline & & 9.09 & categorical scale & 6.4 & 6.9 & 7.8 & 6.6 \\
\hline & & 10.81 & (1=dislike & 6.8 & 6.8 & 6 & 6.6 \\
\hline & & 11.77 & extremely to $9=$ like & 6.6 & 6.6 & 5.9 & 6.6 \\
\hline & & 13.64 & extremely) & 6.6 & 6.6 & 5.6 & 6.4 \\
\hline \multirow[t]{2}{*}{ Baixauli et al. } & \multirow[t]{2}{*}{$2008 b$} & $6.3 \mathrm{C}$ & 9 point hedonic & 7 & 7 & 7.2 & 7 \\
\hline & & 9.4 & $\begin{array}{l}\text { categorical scale } \\
\text { (1=dislike } \\
\text { extremely to } 9=\text { like } \\
\text { extremely) }\end{array}$ & 6.1 & 6 & 5.9 & 6 \\
\hline \multirow[t]{5}{*}{ Vieira et al. } & \multirow[t]{5}{*}{2008} & $2.6 \mathrm{C}$ & 9 point hedonic & . & . & . & 7.98 \\
\hline & & 3.7 & categorical scale & . & . & . & 7.5 \\
\hline & & 4.7 & (1=dislike & . & . & . & 7.49 \\
\hline & & 5.73 & extremely to $9=$ like & . & . & . & 7.35 \\
\hline & & 6.75 & extremely) & . & . & . & 7.33 \\
\hline \multirow[t]{13}{*}{ Sabanis et al. } & \multirow[t]{13}{*}{2009} & $2.1 \mathrm{C}$ & 9 point hedonic & 6 & 6 & 6.5 & 5.8 \\
\hline & & 3.5 & categorical scale & 6.2 & 5.8 & 6.8 & 6 \\
\hline & & 5.2 & (1=dislike & 5.5 & 5.5 & 6 & 5.8 \\
\hline & & 7.1 & extremely to $9=$ like & 5.3 & 5.2 & 5.5 & 5.5 \\
\hline & & 3.5 & Extremely) & 7.5 & 7.2 & 8 & 7.5 \\
\hline & & 5.2 & & 7.1 & 7.5 & 7.5 & 6.5 \\
\hline & & 7.1 & & 7 & 6.5 & 7.2 & 6.7 \\
\hline & & 3.5 & & 7.5 & 6 & 6.5 & 6.7 \\
\hline & & 5.2 & & 7.5 & 6 & 6.3 & 6.5 \\
\hline & & 7.1 & & 6.5 & 5.5 & 6 & 6 \\
\hline & & 3.5 & & 6 & 6.5 & 6.5 & 6.2 \\
\hline & & 5.2 & & 6.5 & 6 & 6.2 & 6 \\
\hline & & 7.1 & & 6 & 5.5 & 6 & 5.5 \\
\hline \multirow[t]{4}{*}{ Laguna et al. } & \multirow[t]{4}{*}{2011} & $4.03 C$ & 9 point hedonic & 6.6 & 6.6 & 6.6 & 6.6 \\
\hline & & 9.01 & categorical scale & 6.5 & 6.6 & 6.5 & 6.5 \\
\hline & & 11.44 & (1=dislike & 6 & 6.6 & 5.9 & 6.4 \\
\hline & & 15.11 & $\begin{array}{l}\text { extremely to } 9=\text { like } \\
\text { Extremely) }\end{array}$ & 5 & 5.1 & 5 & 5 \\
\hline \multirow[t]{5}{*}{ Angiloni \& Collar } & \multirow[t]{5}{*}{2011} & $1.9 \mathrm{C}$ & Overall & . & . & . & 6 \\
\hline & & 7.3 & acceptability & . & . & . & 7.4 \\
\hline & & 7.8 & assessed based on & . & . & . & 7.4 \\
\hline & & 8 & $\begin{array}{l}\text { defined attributes } \\
\text { assessment }\end{array}$ & . & . & . & 6.5 \\
\hline & & 8.3 & $\begin{array}{l}\text { grouped for visual, } \\
\text { textural and } \\
\text { organoleptic } \\
\text { categories } \\
\text { (lowest=1 to } \\
\text { highest }=10 \text { ) }\end{array}$ & . & . & . & 5 \\
\hline \multirow[t]{2}{*}{ Aziah et al. } & \multirow[t]{2}{*}{2012} & $2.24 \mathrm{C}$ & 9 point hedonic & . & 6 & 2.1 & 6.3 \\
\hline & & 5.65 & categorical scale & . & 6.4 & 6.8 & 6.5 \\
\hline
\end{tabular}




\begin{tabular}{|c|c|c|c|c|c|c|c|}
\hline & & 3.64 & $\begin{array}{l}\text { ( } 1=\text { dislike } \\
\text { extremely to } 9=\text { like } \\
\text { Extremely) }\end{array}$ & . & 6.7 & 6.5 & 7.3 \\
\hline $\begin{array}{l}\text { Mildner-Szkudlarz } \\
\text { et al. }\end{array}$ & 2013 & $\begin{array}{l}3.44 \mathrm{C} \\
6.49 \\
8.93 \\
11.03\end{array}$ & $\begin{array}{l}\text { Overall } \\
\text { acceptability rated } \\
\text { using a linear } \\
\text { graphic scale from } \\
0 \text { to } 9 .\end{array}$ & $\begin{array}{l}\cdot \\
\cdot \\
\cdot\end{array}$ & $\begin{array}{l}. \\
. \\
.\end{array}$ & $\begin{array}{l}. \\
. \\
.\end{array}$ & $\begin{array}{l}7.2 \\
6.8 \\
6.2 \\
5.2\end{array}$ \\
\hline Ho et al. & 2013 & $\begin{array}{l}3.68 \mathrm{C} \\
8.51 \\
9.24 \\
9.14\end{array}$ & $\begin{array}{l}7 \text { point hedonic } \\
\text { categorical scale } \\
\text { ( } 1=\text { dislike } \\
\text { very much to } 7=\text { like } \\
\text { very much) }\end{array}$ & . & $\begin{array}{l}5 \\
5 \\
5 \\
5.2\end{array}$ & $\begin{array}{l}5.8 \\
4 \\
4 \\
4\end{array}$ & $\begin{array}{l}5 \\
4.8 \\
4.8 \\
5\end{array}$ \\
\hline Ng \& Wan Rosli & 2013 & $\begin{array}{l}3.35 \mathrm{C} \\
4.51 \\
5.00 \\
5.91\end{array}$ & $\begin{array}{l}7 \text { point hedonic } \\
\text { categorical scale } \\
\text { (1=dislike } \\
\text { the most to } 9=\text { like } \\
\text { the most) }\end{array}$ & $\begin{array}{l}\cdot \\
\cdot \\
\cdot\end{array}$ & $\begin{array}{l}4.9 \\
4.43 \\
4.23 \\
3.97\end{array}$ & $\begin{array}{l}5.13 \\
4.97 \\
4.23 \\
4.25\end{array}$ & $\begin{array}{l}4.98 \\
4.68 \\
4.2 \\
4.08\end{array}$ \\
\hline Nyam et al. & 2013 & $\begin{array}{l}2.30 \mathrm{C} \\
4.30 \\
3.00\end{array}$ & $\begin{array}{l}9 \text { point hedonic } \\
\text { categorical scale } \\
\text { (1=dislike } \\
\text { extremely to } 9=\text { like } \\
\text { Extremely) }\end{array}$ & $\begin{array}{l}6.13 \\
5.40 \\
6.60\end{array}$ & $\begin{array}{l}5.87 \\
5.87 \\
6.67\end{array}$ & $\begin{array}{l}5.87 \\
5.73 \\
6.47\end{array}$ & $\begin{array}{l}6.07 \\
5.87 \\
6.60\end{array}$ \\
\hline Sharma et al. & 2013 & $\begin{array}{l}9.82 \mathrm{C} \\
14.97 \\
14.75 \\
14.59 \\
14.31\end{array}$ & $\begin{array}{l}9 \text { point hedonic } \\
\text { categorical scale } \\
\text { ( } 1=\text { dislike } \\
\text { extremely to } 9=\text { like } \\
\text { Extremely) }\end{array}$ & $\begin{array}{l}7.9 \\
7.4 \\
7.3 \\
7.6 \\
6.7\end{array}$ & $\begin{array}{l}7.8 \\
7.3 \\
7.2 \\
7.8 \\
7.0\end{array}$ & $\begin{array}{l}7.7 \\
7.4 \\
7.6 \\
7.6 \\
6.3\end{array}$ & $\begin{array}{l}7.8 \\
7.3 \\
7.4 \\
7.8 \\
6.6 \\
6\end{array}$ \\
\hline
\end{tabular}

